\title{
Influence of test procedure on timber wall racking performance
}

1 Guillaume Coste BEng, MSc, PhD Structural engineer, MEDITE SMARTPLY, Smartply Europe Ltd, Via Waterford, Ireland (corresponding author: guillaume.coste@mdfosb.com)

2 Abdy Kermani BSc, MSc, PhD, CEng, FIStrucE, FIWSc, FIMMM Director, Centre for Timber Engineering, Edinburgh Napier University, Edinburgh, UK

3 Jack Porteous BSC, MSC, DIC, PhD, CEng, MIStructE, FICE Independent consultant, Centre for Timber Engineering, Edinburgh Napier University, Edinburgh, UK
4 David Murray BTech

Innovation manager, MEDITE SMARTPLY, Smartply Europe Ltd, Via Waterford, Ireland

5. Roshan Dhonju BSCE, MSC Research student, Centre for Timber Engineering, Edinburgh Napier University, Edinburgh, UK
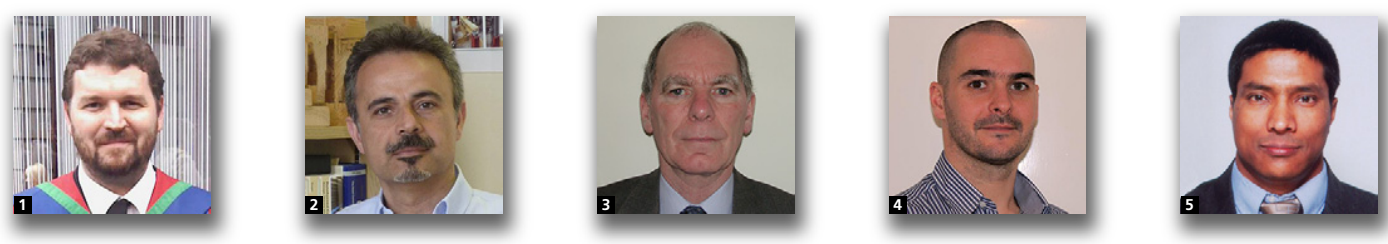

In the UK, the design procedure for calculating the racking strength of timber-framed walls is based on the rules in Eurocode 5 and given in PD 6693-1. Currently, the PD method does not include a procedure for calculating racking strength using the results from wall panel racking tests to BS EN 594. Under the Building Regulations (England and Wales), BS 5268-6.1:1996, which was superseded by Eurocode 5, can still be used and this standard includes a calculation method using test results from BS EN 594:1996. As BS EN 594:2011 uses a revised test procedure, it has been found that the results are no longer compatible with the BS 5268-6.1 design procedure. This paper describes an extensive experimental programme investigating the compatibility and suitability of the test method in BS EN 594:2011 with the racking design method in BS 5268-6.1:1996. The test results have been analysed and compared, and appropriate recommendations are made.

\author{
Notation \\ $F_{\text {fail }} \quad$ racking strength load \\ $F_{i} \quad$ racking load from the test cycle \\ $F_{\text {stiff }} \quad$ racking stiffness load \\ $R \quad$ racking stiffness of timber frame wall \\ $R_{\mathrm{b}} \quad$ basic racking resistance \\ $v_{i} \quad$ racking displacement under $F_{i}$
}

\section{Introduction}

Since the late 1980s the timber frame industry in the UK has been designing wall panels using an empirical method largely based on test results to derive the wall panel racking resistance. Structural designers were provided, in the UK national standard BS 5268-6.1 (BSI, 1988; revised by BSI, 1996a), with a permissible stress design procedure that was able be applied to the design of wall panels constructed using particular sheathing materials such that - providing the installation requirements in the standard had been correctly followed - a basic racking resistance value used to derive the panel racking strength could be taken to apply. Where sheathing panels (wood based and non-wood based) differed from those listed in the UK standard, testing was permitted to derive design data that then enabled the racking resistance of such panels to be calculated using the design procedure given in the standard. However, with the introduction of the limit states Eurocodes, BS 5268-6.1 has been superseded and withdrawn by the British Standards Institution (BSI) for structural timber design and replaced by the requirements of Eurocode 5 (BSI, 2014).

Eurocode 5 provides two design methods for the determination of the racking strength of timber-frame wall systems (referred to in the code as wall diaphragms). The first (method A) was developed to suit the construction procedure where racking walls are fully anchored at their ends, which is a method commonly used in mainland Europe countries, but not in the UK. The second (method B) was an attempt to convert the UK racking procedure referred to in BS 5268-6.1, in which racking walls are generally connected to support structure along their lengths, to a limit states design procedure. However some important aspects of the UK method were omitted or incorrectly interpreted by the codifiers in that process and this led to the 
development of a unified method by UK and European researchers (Griffiths et al., 2005). The unified method was not adopted for UK design but another method was developed and included in PD 6693-1 (BSI, 2012a), and the UK National Annex to Eurocode 5 (BSI, 2012b) requirement is that the PD method should be used to derive racking resistance rather than method $\mathrm{B}$. This method models wall behaviour based on plastic theory, drawing on research by Kallsnër and Girhammar (2004) as well as results from extensive wall tests (Porteous and Kermani, 2013).

Independent of the development of the calculation method in PD 6693-1 (BSI, 2012a), the standard used for the derivation of racking strength and stiffness of timber frame wall panels through testing, EN 594, was also revised and modified. The test method was originally developed and included in the timber structural design standard (BSI, 1988) and, when the national standard was revised (BSI, 1996a), a specific test standard, based on the original method, was adopted as the European standard BS EN 594 (BSI, 1996b). This standard has since been further revised (BSI, 2011), introducing significant changes in the test procedure. The loading cycle requirement up to $40 \%$ of the failure load (which had been introduced to be able to derive stiffness properties of the wall panel at the stage when stability in load-displacement behaviour under this load level would have been considered to have been reached) has been removed and the overall test duration has been greatly reduced. The revisions to this standard took place at the time when BS 5268-6.1: 1996 was in the process of being replaced by Eurocode 5 and it is to be questioned that the linkage between the test procedure in BS EN 594:2011 and the racking design procedure in BS 5268-6.1:1996 was considered in the revision process. It is also to be noted that the racking strength method in PD 6693-1 is a design approach that draws on the design rules in Eurocode 5 and, unlike the racking procedure in BS 5268-6.1:1996, there is at present no procedure for being able to use the results from racking wall tests to BS EN 594 in the PD method to derive racking strength. Where there is a requirement to derive the racking strength of timber-framed wall panels from the results of racking tests, the only calculation method that will currently permit this is the design procedure given in BS 5268-6.1 (BSI, 1988, 1996a).

The adoption of Eurocodes by the UK timber industry has been slow, and, as BS 5268-6.1:1996 is still a design standard accepted in England and Wales by the Building Regulations, it is still acceptable to produce design calculations in accordance with this standard. The timber frame industry is therefore in a situation where, for various reasons, this standard is still being used by designers to determine the racking strength of timber frame wall systems. Consequently, design engineers request the wood panel industry to test and categorise wall sheathing products to BS 5268-6.1:1996; however, because of the changes to BS EN 594:2011, test results are consistently lower than those obtained using the test procedure in BS EN 594:1996, leading to panels failing to achieve the basic racking resistance values given in BS 5268-6.1:1996.

To investigate this situation, an extensive experimental programme was undertaken at the Centre for Timber Engineering at Edinburgh Napier University to determine the compatibility and suitability of the current racking test method given in BS EN 594:2011 (BSI, 2011) with the structural design method still used by engineers in the UK, detailed in BS 5268-6.1 (BSI, 1996a). The experimental programme included racking tests on a variety of wood-based panels with different vertical loadings, using both the 1996 and 2011 versions of BS EN 594 (BSI, 1996b, 2011). The test results are analysed, compared and discussed in the following sections.

\section{Test method evolution}

The basic test panel used for a racking test has not changed throughout the code revision and evolution process. It is a $2.40 \mathrm{~m}$ by $2.40 \mathrm{~m}$ timber frame with evenly spaced studs on which typical $2.4 \mathrm{~m}$ by $1.2 \mathrm{~m}$ panels are fixed, as shown in Figure 1. These dimensions were used as they were the standard wall panel dimensions when the test method was first developed and allow the use of standard sheathing panels. The racking deflection of the wall panel is calculated as the displacement at position \#1 minus the displacement at position \#2.

The initial test method for the determination of the racking strength and stiffness of a timber frame wall panel was developed by Griffiths (1987) at the University of Surrey as part of his $\mathrm{PhD}$ work to derive a procedure for calculating a wall panel racking strength. From his extensive research, the British Standard test method and the design method for determining racking resistance were derived. The test method was divided into a stiffness test followed by a strength test. Following a racking preload causing a deflection of $0.0005 \times$ wall panel height, the stiffness test included applying a racking load up to a deflection of $0.002 \times$ wall panel height, reaching the deflection within 4-10 min, and the racking load was then removed. This loading cycle was repeated four times and on the fourth cycle the racking load was increased until failure of the wall system, ensuring that the racking deflection did not exceed $15 \mathrm{~mm}$ every $5 \mathrm{~min}$. Each wall panel test required about 50-65 min to completion. From the test, a racking stiffness load and a racking strength load were determined.

In the development of the stiffness behaviour of the wall panel it was found that panel behaviour stiffened under cyclic lateral loading and it was concluded that four load cycles should be used for the standard test, by which time a stable cycle would have been reached, or would be close to being reached. It was also noted that the testing regime should concentrate on the initial stiffness of wall panels as this was likely to be the governing factor in the majority of design cases (Griffiths, 1987). 

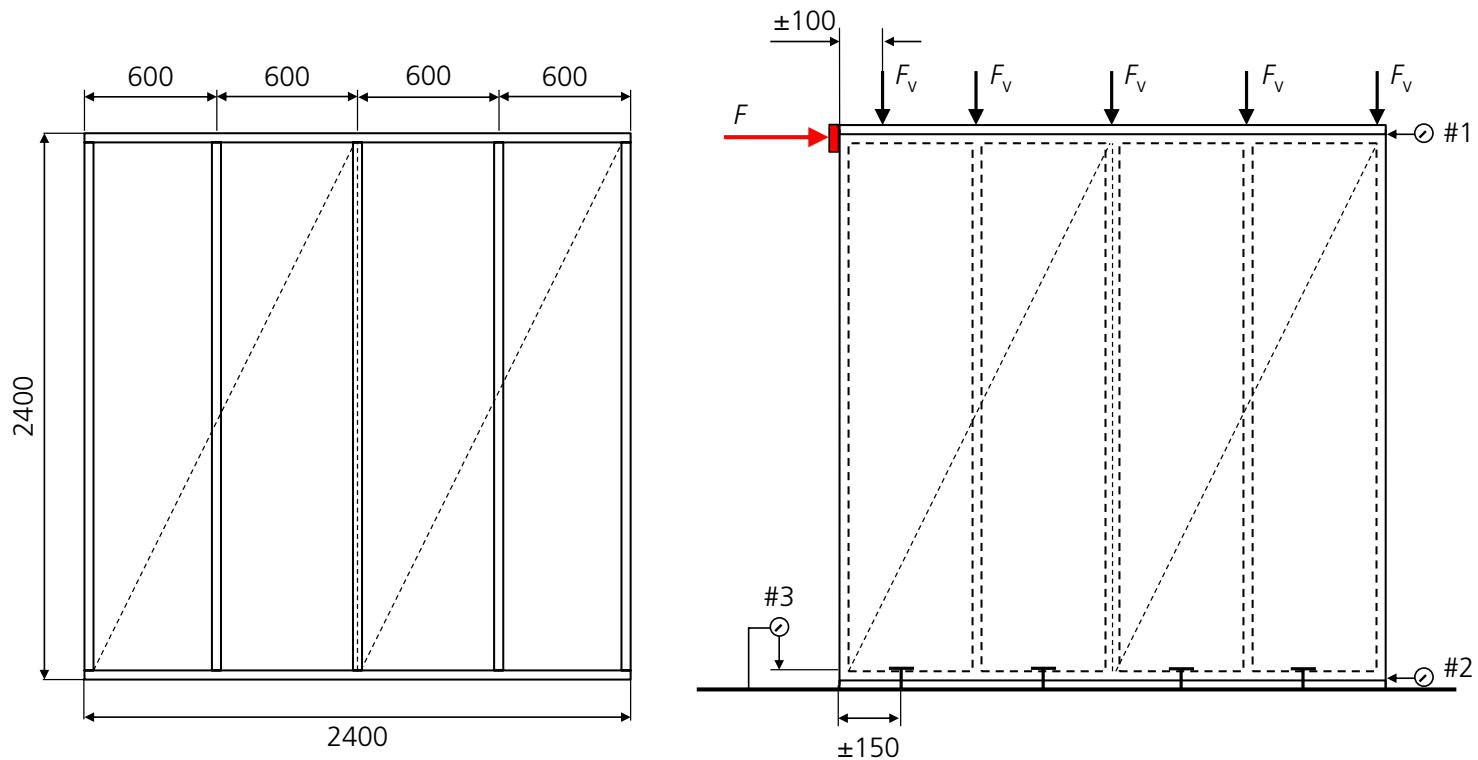

Figure 1. Racking test timber frame panel with dimensions (in $\mathrm{mm}$ ) and setup with racking and vertical loads and position of displacement measurements

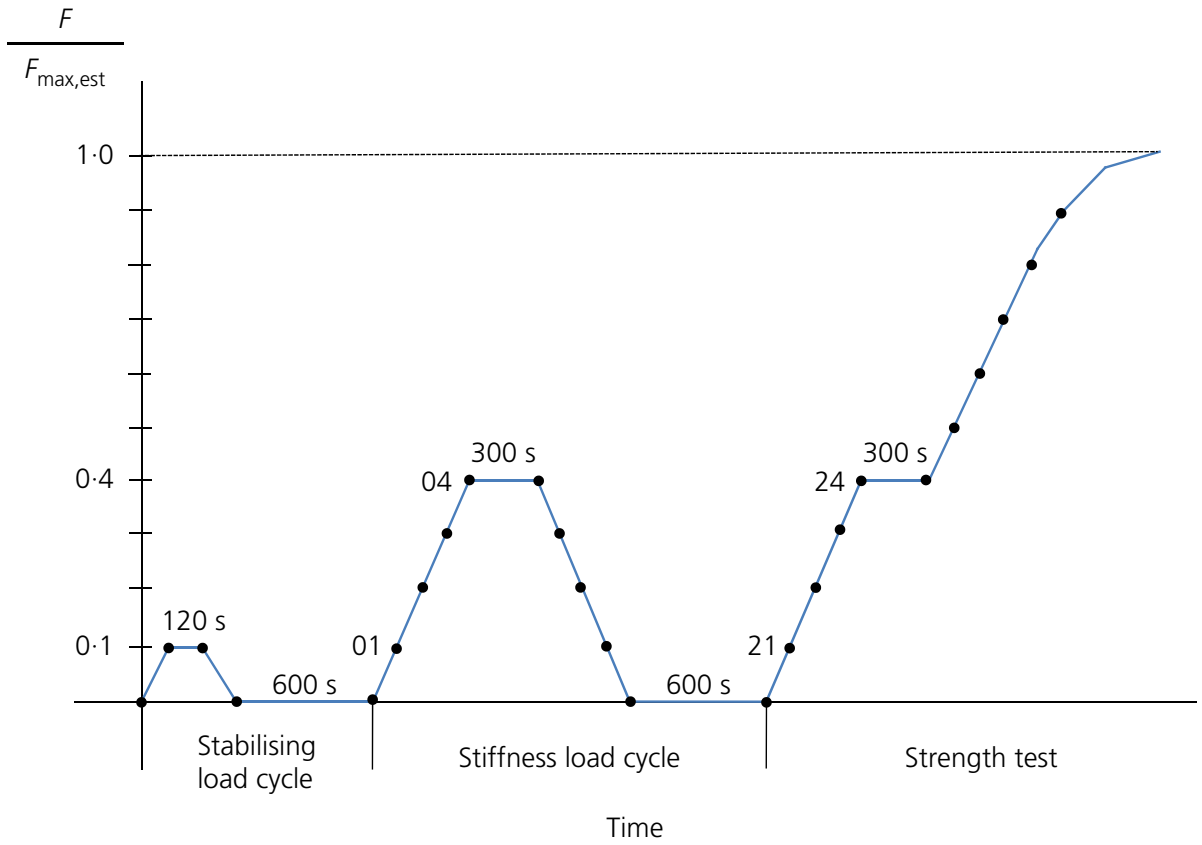

Figure 2. BS EN 594:1996 racking test load cycle

In the next revision of the British Standard, the racking test method was detailed in a specific European standard, EN 594 (BSI, 1996b). The principle of the test from the original test method was retained but the overall test cycle for a wall panel was reduced in order to shorten the test duration. The full test cycle required under this revision is shown in Figure 2. The main change from 1988 was that an estimated racking load $\left(F_{\text {max,est }}\right)$ was required and the stiffness test was reduced to effectively two load cycles as opposed to four in the original test requirement. However, this change did not warrant any 
change to the procedure that was used to derive the racking strength of the wall.

From the EN 594:1996 test procedure, a racking stiffness and racking strength load is determined. The racking stiffness $(R$, in $\mathrm{N} / \mathrm{mm})$ is determined from

1. $R=\frac{1}{2}\left(\frac{F_{04}-F_{01}}{v_{04}-v_{01}}+\frac{F_{24}-F_{21}}{v_{24}-v_{21}}\right)$

where $F_{i}$ is the racking load from the test load cycle (in N) and $v_{i}$ is the racking displacement under $F_{i}$ (in $\mathrm{mm}$ ).

The 2011 revision of BS EN 594 (BSI, 2011) is stated to have been undertaken to increase the scope for more types of panel and to allow a more straightforward comparison between results of different panels. It was considerably modified, resulting in the removal of the stiffness cycle procedure as well as a significant reduction in the test duration. The requirement is to undertake a stabilising load cycle, where a vertical load of $1 \mathrm{kN}$ is applied to the studs for a period of $120 \mathrm{~s}$, then, following a recovery period of $600 \pm 300 \mathrm{~s}$, the strength test is conducted as shown in Figure 3.

The main modifications applied to the test method as approved in 2011 were the exclusion of the stiffness load cycle procedure as part the test and the method of calculation of the racking stiffness (Equation 2). The racking stiffness is derived from the strength test and calculated by taking load and deflection results from the test between $20 \%$ and $40 \%$ of the maximum load when it was previously between $10 \%$ and $40 \%$ of the maximum load. Also, from the original test method to the current procedure, the test duration was reduced from about an hour to one requiring that $90 \%$ of the racking load



Figure 3. BS EN 594:2011 load versus displacement test procedure (adapted from BSI, 2011) should be reached within $300 \pm 120 \mathrm{~s}$

2. $R=\left(\frac{F_{4}-F_{2}}{v_{4}-v_{2}}\right)$

In Equation 2, again, $F_{i}$ represents the racking load from the test load cycle (in $\mathrm{N}$ ) and $v_{i}$ is the racking displacement under $F_{i}$ (in $\mathrm{mm}$ ).

The modifications, including the exclusion of the stiffness load cycle procedure and the changes in the stiffness calculation method, have significantly altered the input values to be used in the determination of the racking performance of the timber frame panels and, as stated previously, it is to be questioned that the effects of such changes on design values used to derive racking strength have been fully evaluated.

\section{Racking resistance of walls}

From his investigations into the racking behaviour of timber frame walls, Griffiths (1987) derived a method for calculating the racking resistance of such walls, which was codified and incorporated in BS 5268-6.1:1988. The codified procedure enabled the racking resistance of a timber frame wall system to be determined by either an 'assessment method', using a calculation procedure incorporating strength behaviour derived from test evidence, or by load testing. Both methods are based on the use of a 'basic racking resistance' $\left(R_{\mathrm{b}}\right)$, which is modified by other factors to derive the racking strength value.

In the assessment method, the basic racking resistance values of some materials had been derived by Griffiths from test results and incorporated into the code, as shown in Table 1. For a timber wall frame constructed using a board material listed in Table 1, the associated basic racking resistance value to be used to derive the design racking strength is modified by various factors that include nail diameter, nail spacing, sheathing thickness, wall height, openings in the frame and wall length.

For the load testing method, the design racking strength is derived as above but using a basic racking resistance obtained from the results of a number of tests performed in accordance with section 5 of BS 5268-6.1:1988, or, for the subsequent revision of this standard (BS 5268-6.1:1996), using BS EN 594 test results. The basic racking resistance is calculated as follows.

Determination of the racking stiffness load $\left(F_{\text {stiff, }}\right.$ in $\left.\mathrm{kN}\right)$ is by means of

3. $\quad F_{\text {stiff }}=R \times 0.002 \times H_{\mathrm{wp}} \times 1.25 \times K_{109}$

where $R$ is the average racking stiffness loads of similar panels (in $\mathrm{kN} / \mathrm{mm}$ ), $H_{\mathrm{wp}}$ is the wall panel height (in $\mathrm{mm}$ ) and $K_{109}$ is a modification factor to account for the number of similar 


\begin{tabular}{|c|c|c|c|c|}
\hline \multirow[b]{2}{*}{ Primary board material } & \multirow[b]{2}{*}{ Fixing } & \multirow[b]{2}{*}{$\begin{array}{l}\text { Racking } \\
\text { resistance: } \\
\text { kN/m }\end{array}$} & \multicolumn{2}{|c|}{$\begin{array}{l}\text { Additional contribution of } \\
\text { secondary board on timber } \\
\text { frame wall: } k \mathrm{k} / \mathrm{m}\end{array}$} \\
\hline & & & $\begin{array}{c}\text { Category } 2 \text { or } \\
3 \text { materials }\end{array}$ & $\begin{array}{c}\text { Category } 1 \\
\text { material }\end{array}$ \\
\hline $\begin{array}{l}\text { Category } 1 \text { materials } \\
9.5 \mathrm{~mm} \text { plywood } \\
9.0 \mathrm{~mm} \text { medium board } \\
12.0 \mathrm{~mm} \text { chipboard (type } \\
\text { C3M, C4M or C5) } \\
6.0 \mathrm{~mm} \text { tempered hardboard } \\
9.0 \mathrm{~mm} \mathrm{OSB} / 3\end{array}$ & $\begin{array}{l}3.00 \mathrm{~mm} \text { diameter wire nails at least } \\
50 \mathrm{~mm} \text { long, maximum spacing } 150 \mathrm{~mm} \\
\text { on perimeter, } 300 \mathrm{~mm} \text { internal }\end{array}$ & 1.68 & 0.28 & $0 \cdot 84$ \\
\hline $\begin{array}{l}\text { Category } 2 \text { materials } \\
12.5 \mathrm{~mm} \text { bitumen- } \\
\text { impregnated insulation board }\end{array}$ & $\begin{array}{l}3.00 \mathrm{~mm} \text { diameter wire nails at least } \\
50 \mathrm{~mm} \text { long, maximum spacing } \\
75 \mathrm{~mm} \text { on perimeter, } 150 \mathrm{~mm} \text { internal }\end{array}$ & 0.9 & 0.45 & 1.06 \\
\hline $\begin{array}{l}\text { Separating wall of minimum } \\
30 \mathrm{~mm} \text { plasterboard } \\
\text { (in two or more layers) }\end{array}$ & $\begin{array}{l}\text { Each layer should be individually fixed with } \\
2.65 \mathrm{~mm} \text { diameter plasterboard nails at } \\
150 \mathrm{~mm} \text { spacings, nails for the outermost layer } \\
\text { should be at least } 60 \mathrm{~mm} \text { long }\end{array}$ & 0.9 & 0.45 & 1.06 \\
\hline $\begin{array}{l}\text { Category } 3 \text { materials } \\
12.5 \mathrm{~mm} \text { plasterboard }\end{array}$ & $\begin{array}{l}2.65 \mathrm{~mm} \text { diameter plasterboard nails at least } \\
40 \mathrm{~mm} \text { long, maximum spacing } 150 \mathrm{~mm}\end{array}$ & 0.9 & 0.45 & 1.06 \\
\hline $\begin{array}{l}\text { Table 1. Basic racking resistance for } \\
\text { combination of materials (BS 5268-6 } \\
\text { BS 5268-6.1:1996 (BSI, 1996a)) }\end{array}$ & $\begin{array}{l}\text { a range of materials and } \\
1: 1988 \text { (BSI, 1988) and }\end{array}$ & & & \\
\hline
\end{tabular}

panels tested under the same conditions: for example, for one test $K_{109}=0 \cdot 8$, for three tests $K_{109}=0.93$ and for five tests $K_{109}=1 \cdot 0$.

The racking strength load $\left(F_{\text {fail }}\right.$, in $\left.\mathrm{kN}\right)$ is determined from

4. $\quad F_{\text {fail }}=\frac{F_{\text {max } \min } \times K_{109}}{\mathrm{FoS}}$

where $F_{\text {max,min }}$ is the lowest failure (or maximum) racking load achieved during the tests of similar panels (in $\mathrm{kN}$ ) and $\mathrm{FoS}$ is a factor of safety for the type of sheathing or sheathing combination: for any material or combination of two materials that includes plasterboard, $\mathrm{FoS}=2 \cdot 4$, and for any material or combination of two materials that excludes plasterboard, $\mathrm{FoS}=1 \cdot 6$.

The basic racking resistance $\left(R_{\mathrm{b}}\right.$, in $\left.\mathrm{kN} / \mathrm{m}\right)$ is then calculated from

$$
\text { 5. } \quad R_{\mathrm{b}}=\frac{\min \left\{F_{\text {stiff }} ; F_{\text {fail }}\right\}}{2 \cdot 4 K_{111}}
$$

where $K_{111}$ is a modification factor to account for vertical loading on the studs: for example, for no vertical load $K_{111}=1 \cdot 0$, for a load of $1 \mathrm{kN} /$ stud $K_{111}=1 \cdot 18$, for $2.5 \mathrm{kN} /$ stud $K_{111}=1.43$ and for $5 \mathrm{kN} /$ stud $K_{111}=1 \cdot 77$.

As can be seen from the above, the determination of the test racking stiffness can have a direct effect on the determination of the basic racking strength and consequently on the design racking resistance of a timber frame wall. Therefore, any modifications in the test method or calculation method of the racking stiffness that will influence stiffness behaviour have the potential to affect the racking design strength of a panel.

\section{Experimental programme and results}

\subsection{Test setup and programme}

An extensive experimental programme was conducted at the Centre for Timber Engineering at Edinburgh Napier University on a range of OSB/3 panels, manufactured by Smartply Europe in Ireland, in order to evaluate the racking performance of timber frame panels when tested to the 1996 and 2011 versions of BS EN 594 (BSI, 1996b, 2011). The tests on timber frame wall panels consisted of a series of predetermined geometrically configured walls of $2.4 \mathrm{~m} \times 2.4 \mathrm{~m}$ in size comprising a range of $\mathrm{OSB} / 3$ panels of varying thicknesses, fixed to one side only of the timber framing. The wall framing was studs/timber sections of $45 \times 90 \mathrm{~mm}$ or $38 \times 89 \mathrm{~mm} \mathrm{C16}$ timbers (covering 
the range of breadth used in wall construction) and the panels were fixed using $3.0 \mathrm{~mm}$ round wire nails, $50 \mathrm{~mm}$ long, with nailing density/patterns of 150/300 around the perimeter and at internal studs, as detailed in Table 2.

The wall panels were tested in an upright position, as shown in Figure 4 . The bottom rail was connected to the test bed using four M12 $\times 150 \mathrm{~mm}$ long bolts. Lateral restraints (to prevent lateral distortion) were provided by means of two pairs of rollers at the top plate (header level) which permitted free inplane movement of the wall both in the vertical and horizontal directions.

Loads were applied using two separate loading systems.

- The racking load was applied by a horizontal jack connected to an automatic/computerised loading and data acquisition system that followed a pre-programmed loading procedure based on either BS EN 594:1996 or BS EN 594:2011, as appropriate.

- The vertical loading, when used, was applied through an air bag pressurised to provide a constant $25 \mathrm{kN}$ uniformly distributed loading (UDL), which in turn was transferred to the head binder at stud positions as point loads, through rollers.

Displacement transducers were used to record the horizontal movement of the walls at the leeward base (point \#2) and the header levels (point \#1) and the vertical uplift of the lead stud, including any movement of the sole plate at this position, on the loaded side of the wall (point \#3).

For tests to BS EN 594:2011 (BSI, 2011), a stabilising UDL vertical load of $5 \mathrm{kN}$ (in total) was applied through the air bag to the head binder at the stud positions and maintained for $120 \mathrm{~s}$. The load was then removed and the panel was allowed to recover for a period of $600 \mathrm{~s}$ before the strength test was carried out. For walls under vertical loading, a constant UDL vertical load of $25 \mathrm{kN}$ was applied through the air bag to the head binder at the stud positions and maintained throughout the racking test. The horizontal racking load was then applied at a steady rate in which $90 \%$ of the maximum load was reached within $300+120 \mathrm{~s}$.

For tests to BS EN 594:1996 (BSI, 1996b), the test procedure followed that described in section 6.4 of the standard, with the test loading applied as illustrated in Figure 2.

\subsection{Test results}

The results of all the tests are presented in Table 2 and the racking stiffness $(R)$ was calculated as recommended for the relevant test standard used. Guidance is given in BS 5268-6.1 (BSI, 1988, 1996a) on how to calculate the racking stiffness load $\left(F_{\text {stiff }}\right)$, racking strength load $\left(F_{\text {fail }}\right)$ and the basic racking resistance $\left(R_{\mathrm{b}}\right)$ and the calculated values of these functions 




Figure 4. Racking test panel with vertical loads

are also given in Table 2 for the walls tested in accordance with the requirements of BS EN 594:1996 (BSI, 1996b) or BS EN 594:2011 (BSI, 2011) where appropriate. The failure behaviour of all wall panels was recorded as recommended in the test standard and ductile failure behaviour was observed in all instances.

The results show that, for all tests undertaken in accordance with BS EN 594:1996, $R_{\mathrm{b}}$ for the sheathing panel material used exceeds the value of 1.68 given in BS 5268-6.1 (BSI, 1996a). However, for the wall panels tested using the same panel material type but in accordance with BS EN 594:2011 and analysed using the method given in BS 5268-6.1, no wall panel achieved the category 1 requirements as defined in BS 5268-6.1 and shown in Table 1. It is also to be noted that, apart from test 2 , the critical design condition was always due to stiffness rather than strength behaviour.

\section{Analysis and discussion}

The results of the experimental programme show there is a clear difference in the basic racking resistance for the same wood-based panels when tested to the two different versions of the European standard BS EN 594 (BSI, 1996b, 2011). As stated in Section 2, with the reduction in the test duration from about an hour to requiring the test to be completed within $300 \pm 120 \mathrm{~s}$, as well as the exclusion of the stiffness load cycle and the changes in the stiffness calculation method, when using BS EN 594:2011 there are likely to be consequences on panel behaviour and this was shown to be the case by the test results.

From the test results, a comparison of the strength at failure and stiffness at the serviceability condition between identical wall panels tested to BS EN 594:1996 and to BS EN 594:2011 is shown in Figure 5. For strength behaviour, as shown in

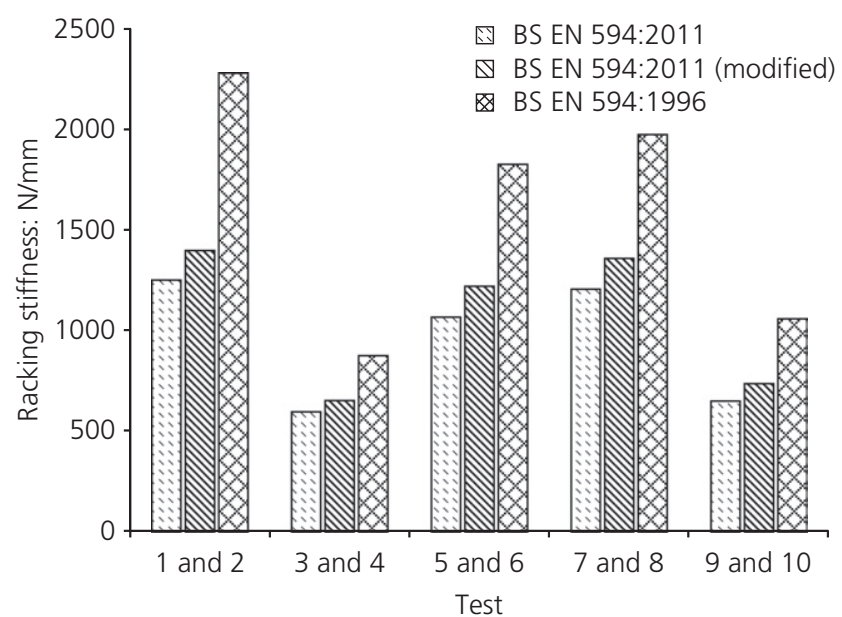

(a)

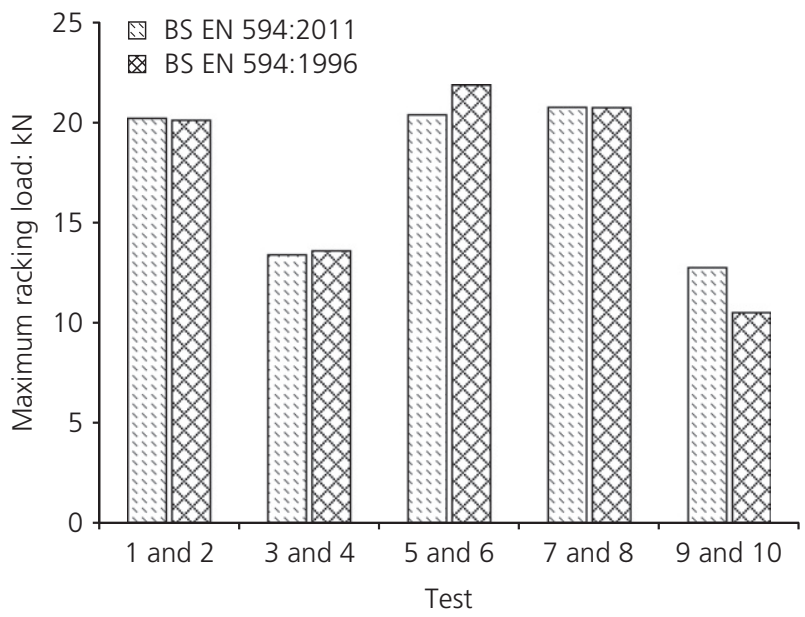

(b)

Figure 5. Comparison of racking stiffness (a) and load (b) for identical wall panels tested under different test procedures 
BS EN 594:2011 BS EN 594:1996 Variation: \%

\begin{tabular}{|c|c|c|c|}
\hline & Test 1 & Test 2 & \\
\hline$F_{\text {max }}: \mathrm{kN}$ & $20 \cdot 22$ & $20 \cdot 13$ & -0.4 \\
\hline$R: \mathrm{N} / \mathrm{mm}$ & $1252 \cdot 40$ & $2281 \cdot 15$ & $82 \cdot 1$ \\
\hline$R_{1}: \mathrm{N} / \mathrm{mm}$ & - & $1899 \cdot 51$ & $51 \cdot 7$ \\
\hline \multirow[t]{2}{*}{$R_{2}: \mathrm{N} / \mathrm{mm}$} & - & $2662 \cdot 78$ & $112 \cdot 6$ \\
\hline & Test 3 & Test 4 & \\
\hline$F_{\text {max }}: \mathrm{kN}$ & $13 \cdot 41$ & $13 \cdot 60$ & $1 \cdot 5$ \\
\hline$R: \mathrm{N} / \mathrm{mm}$ & $597 \cdot 15$ & $876 \cdot 36$ & 31.9 \\
\hline$R_{1}: \mathrm{N} / \mathrm{mm}$ & - & $706 \cdot 02$ & $18 \cdot 2$ \\
\hline \multirow[t]{2}{*}{$R_{2}: \mathrm{N} / \mathrm{mm}$} & - & $1046 \cdot 70$ & $75 \cdot 3$ \\
\hline & Test 5 & Test 6 & \\
\hline$F_{\max }: \mathrm{kN}$ & $20 \cdot 40$ & 21.89 & $6 \cdot 8$ \\
\hline$R: \mathrm{N} / \mathrm{mm}$ & $1068 \cdot 17$ & $1828 \cdot 16$ & $41 \cdot 6$ \\
\hline$R_{1}: \mathrm{N} / \mathrm{mm}$ & - & $1556 \cdot 68$ & $45 \cdot 7$ \\
\hline \multirow[t]{2}{*}{$R_{2}: \mathrm{N} / \mathrm{mm}$} & - & $2002 \cdot 02$ & $87 \cdot 4$ \\
\hline & Test 7 & Test 8 & \\
\hline$F_{\text {max }}: \mathrm{kN}$ & $20 \cdot 78$ & $20 \cdot 76$ & $-0 \cdot 1$ \\
\hline$R: \mathrm{N} / \mathrm{mm}$ & $1207 \cdot 24$ & $1975 \cdot 96$ & 38.9 \\
\hline$R_{1}: \mathrm{N} / \mathrm{mm}$ & - & $1539 \cdot 96$ & $27 \cdot 6$ \\
\hline \multirow[t]{2}{*}{$R_{2}: \mathrm{N} / \mathrm{mm}$} & - & 2411.95 & 99.8 \\
\hline & Test 9 & Test 10 & \\
\hline$F_{\max }: \mathrm{kN}$ & $12 \cdot 76$ & $10 \cdot 52$ & $-21 \cdot 4$ \\
\hline$R: \mathrm{N} / \mathrm{mm}$ & $650 \cdot 60$ & $1059 \cdot 50$ & 38.6 \\
\hline$R_{1}: \mathrm{N} / \mathrm{mm}$ & - & 959.68 & $47 \cdot 5$ \\
\hline$R_{2}: \mathrm{N} / \mathrm{mm}$ & - & $1159 \cdot 33$ & $78 \cdot 2$ \\
\hline
\end{tabular}

Table 3. Result variations between panels tested under different test procedures

Figure 5(b), the racking strength load is similar for both test procedures and for the walls tested there was an average variation between results of just $-2 \cdot 7 \%$. The revised test procedure appears to have no significant effect on the failure strength of a wall panel.

For stiffness behaviour, however, shown in Figure 5(a), there is a clear difference between the results of the wall panels tested under the two procedures. Tests to BS EN 594:1996 consistently resulted in stiffness values greater than those derived from BS EN 594:2011; on average, the stiffness was over 46.6\% greater than the stiffness of identical wall panels tested to BS EN 594:2011.

The results of wall panels tested under similar loading but to the 1996 and the 2011 test procedures of BS EN 594 are compared in Table 3. The variation, in percentage terms, between the maximum racking loads $\left(F_{\max }\right)$ and between the racking stiffness values $(R)$ for the respective test procedures have been calculated. In addition, for those panels tested in accordance with the BS EN 594:1996 procedures, Table 3 also includes the stiffness results for each of the two load cycles defined in Figure 2. These are referred to as $R_{1}$ and $R_{2}$, which were calculated using

$$
\text { 6. } R_{1}=\left[\frac{F_{04}-F_{01}}{v_{04}-v_{01}}\right]
$$

7. $R_{2}=\left[\frac{F_{24}-F_{21}}{v_{24}-v_{21}}\right]$

Table 3 compares the strength and stiffness values of the tests illustrated in Figure 5 and, in addition, also shows that the stiffness calculated as part of the strength test described in Figure $2\left(R_{2}\right)$ is consistently higher than the stiffness calculated as part of the stiffness cycle $\left(R_{1}\right)$. The stiffness increase ranges from $21 \%$ to $57 \%$ with an average value $39 \%$. This demonstrates that wall panels subjected to cyclic loading up to $40 \%$ of the failure load (i.e. within the serviceability limit state) will stiffen up under repeated racking loading and this was the behaviour that Griffiths (1987) took into account when developing the original test procedure for racking walls incorporated into BS 5268-6.1:1996 (BSI, 1996a). By deleting the load cycling procedure, the stiffness will be reduced and this is clearly demonstrated from the test results.

However, the variation between stiffness results to BS EN 594:1996 (BSI, 1996b) and BS EN 594:2011 (BSI, 2011) may not be fully attributed to the difference in the number of test cycles. It is anticipated that the initial settling vertical load of $1 \mathrm{kN} / \mathrm{stud}$ does not eliminate any slack in the plane of the wall panel and therefore has only limited effect on the initial stiffness result. It is therefore considered that the rate of loading and stiffness calculation method between $20 \%$ and $40 \%$ of the maximum load play a part in reducing the stiffness values compared with tests to BS EN 594:1996. As the test programme did not include any tests with varying loading rates, only the stiffness calculation method is evaluated here.

To further compare the effect of the different procedures, a stiffness value was calculated between $10 \%$ and $40 \%$ of the maximum load for all tests to BS EN 594:2011 and, from the initial stiffness, the new stiffness calculated was on average $11.5 \%$ greater. This is shown on Figure 5 as the 'modified' stiffness values. However, this method of calculation of the stiffness according to BS EN 594:2011 still does not compare with the results obtained when using BS EN 594:1996.

A significant issue affecting these results is how the value of the racking stiffness load ( $\left.F_{\text {stiff }}\right)$ is calculated. The stiffness test procedure in BS EN 594:1996 involves more than one load cycle and to convert this frequency of loading to an equivalent 


\begin{tabular}{llll} 
Test & $R_{\mathrm{b}}$ & $R_{1 \mathrm{~b}}$ & Increase: \% \\
\hline 1 & 1.49 & 1.78 & $19 \cdot 6$ \\
3 & 1.39 & 1.67 & $19 \cdot 9$ \\
5 & 1.4 & 1.68 & $20 \cdot 3$ \\
7 & 1.58 & 1.9 & 20.4 \\
9 & 1.4 & 1.68 & $20 \cdot 1$
\end{tabular}

Test Respective $R_{1 \mathrm{~b}}$ values Ratio of respective $R_{1 \mathrm{~b}}$ values

Table 4. Comparison of $R_{\mathrm{b}}$ and $R_{1 \mathrm{~b}}$ values from Table 2

\begin{tabular}{lll}
\hline 2,1 & $2 \cdot 49,1.78$ & 1.40 \\
4,3 & $2.04,1.67$ & 1.22 \\
6,5 & $2 \cdot 40,1.68$ & 1.43 \\
8,7 & $2.60,1.90$ & 1.37 \\
10,9 & $2.46,1.68$ & 1.46
\end{tabular}

Table 5. Comparison of the ratio of $R_{1 \mathrm{~b}}$ values for similar tests

once in 50 year wind return period single cycle condition, required for the derivation of the racking stiffness load, a factor of 1.25 is applied. The 1.25 factor is shown in Equation 3 (Griffiths, 1987). In the BS EN 594:2011 test procedure there is no stiffness load cycling and so for tests to this standard the use of this factor is not appropriate. The racking stiffness load at a deformation of $0.003 \times$ the wall panel height $\left(F_{\text {stiff }}\right)$ will be derived from $R \times 0.003 \times$ wall panel height and this relationship was used to derive this load for the test results from the BS EN 594:2011 test procedure. The racking stiffness load calculated on this basis for these tests is given in the column headed $F_{1 \text { stiff }}$ in Table 2, together with the racking stiffness loads for those tests undertaken using the BS EN 594:1996 test procedure and calculated in accordance with the requirements of BS 5268-6.1 (BSI, 1996a). The value of the basic racking resistance derived from the $F_{\text {fail }}$ and $F_{1 \text { stiff values calculated in }}$ accordance with the requirements of Equation 5 are given in the column headed $R_{1 \mathrm{~b}}$ in Table 2 . A comparison of the basic racking resistance values for the tests carried out using the BS EN 594:2011 test procedure and derived using the above approach with those derived using the BS 5268-6.1 (BSI, 1996a) requirement is given in Table 4 and this shows that the average increase in the value is $20 \cdot 1 \%$.

To confirm the revised value derived for the racking stiffness load would not exceed the deflection limit of $7 \cdot 2 \mathrm{~mm}$ (i.e. $0.003 \times 2.4 \mathrm{~m}$ ), the deflection behaviour of each wall panel at its racking stiffness load was checked and shown to be less than this value. As a further check, the racking strength stiffness used in the derivation of $R_{1 \mathrm{~b}}$ for each test reference was compared with the equivalent test stiffness derived on a conservative basis by using the test load at a deformation of $7.2 \mathrm{~mm}$; in all instances the stiffness value was less than the equivalent value obtained from the test.

Comparing the value of the basic racking resistance $\left(R_{1 \mathrm{~b}}\right)$ for wall panel tests having the same configuration but tested under BS EN 5942011 and 1996 regimes, the ratios of the respective test values are listed in Table 5. From these results, the average increase in value is approximately $37 \%$, which gives an indication of the possible effect of the removal of the cyclic loading regime and the overall test period reduction associated with the 2011 procedure.

\section{Conclusions and recommendations}

In the UK, the current design procedure for determining the racking strength of timber-framed wall panels is based on the design rules in Eurocode 5 and is given in PD 6693-1 (BSI, 2012a). However, there is currently no procedure for being able to use the results from the racking strength and stiffness test standard BS EN 594 to calculate racking strength by the PD method.

BS 5268-6.1:1996 (BSI, 1996a), which has been superseded by Eurocode 5 but is still permitted for use under Building Regulations (England and Wales), is still able to be used and is directly linked to BS EN 594, enabling racking strength to be calculated from the results of wall panel tests. The timber frame industry is therefore in a situation where BS 5268-6.1 is still being used by designers to determine the racking strength of timber frame wall systems. Consequently, design engineers request the wood panel industry to test and categorise wall sheathing products to this standard.

The test standard for the racking strength and stiffness of timber-framed wall panels, BS EN 594, was originally developed from the test procedure in BS 5268-6.1 and published as BS EN 594:1996 (BSI, 1996b). It was fully compatible with the design procedure given in BS 5268-6.1 for calculating the racking strength of wall panels using the results from racking tests. In 2011, a revision of the test standard, BS EN 594:2011 (BSI, 2011), was published and it was stated that this was undertaken to increase the scope for more types of panels and to allow a more straightforward comparison between results of different panels. However, the 2011 revision included significant changes in the test procedure to be used. The loading cycle requirement up to $40 \%$ of the failure load, which had been introduced to be able to derive stiffness properties of the wall panel at the stage when stability in load-displacement behaviour under this load level would have been considered to have been reached, had been removed and the overall test duration had been greatly reduced.

It has been found by the industry that the basic racking resistance values given in BS 5268-6.1 (BSI, 1988, 1996a), which had been derived from tests in accordance with the 1996 version of BS EN 594 (BSI, 1996b), could not be achieved 
when the same types of sheathing panel were tested in accordance with the requirements of the 2011 revision. This was investigated by undertaking a number of wall tests to each version of the BS EN 594 standard.

From a programme of wall panel tests undertaken on panels formed using OSB/3 sheathing, incorporating variations in panel thickness, vertical loadings and wall framing sections, the results showed that the failure strength of walls tested to BS EN 594:2011 and BS EN 594:1996 are comparable. However, the stiffness values calculated for similar wall panels showed that results to BS EN 594:1996 were over 46\% greater than the stiffness of panels tested to BS EN 594:2011. Because of this difference, when applying the procedure given in BS 5268-6.1 to calculate the value of the basic racking resistance, it was always significantly lower under the procedure in BS EN 594:2011 than in the procedure in BS EN 594:1996. Furthermore, the basic racking resistance values derived from the tests to BS EN 594:2011 were always less than the basic resistance value given in Table 2 in BS 5268-6.1, confirming the views being expressed by the industry.

The stiffness procedure in BS EN 594:1996 was based on the application of four load cycles and, to convert to the equivalent single annual load cycle load condition, a factor of 1.25 is incorporated in the BS 5268-6.1:1996 calculation procedure. As the BS EN 594:2011 test procedure for stiffness behaviour only uses the equivalent of one load cycle, use of this factor is inappropriate and when it is not used the value of the basic racking resistance is increased and, with the exception of one result (1.67 for test 3 ) lower than the code value (1.68), the results from all other tests equal or exceed the design value (Table 2 ).

Although the approach provides a method for calculating the basic racking resistance that removes the effects of the stiffness cycle procedure to account for the changed loading requirement in the 2011 revision of BS EN 594, the results of the test programme show there will still be a significant underestimation of the value of the basic racking resistance from that which would be achievable had testing to BS EN 594:1996 been used.

Whilst the Building Regulations permit the use of BS 5268$6.1: 1996$ to derive the racking strength of timber frame walls, it is recommended that the test procedure used to derive the basic racking resistance value should remain as that given in BS EN 594:1996.

\section{REFERENCES}

BSI (1988) BS 5268-6.1:1988: Structural use of timber. Code of practice for timber frame walls. Dwellings not exceeding three storeys. BSI, London, UK.

BSI (1996a) BS 5268-6.1:1996: Structural use of timber. Code of practice for timber frame walls. Dwellings not exceeding seven storeys. BSI, London, UK.
BSI (1996b) BS EN 594:1996: Timber structures. Test methods. Racking strength and stiffness of timber frame wall panels. BSI, London, UK.

BSI (2011) BS EN 594:2011: Timber structures. Test methods. Racking strength and stiffness of timber frame wall panels. BSI, London, UK.

BSI (2012a) PD 6693-1:2012: UK non-contradictory complementary information to Eurocode 5: design of timber structures. Part 1: general - common rules and rules for buildings. BSI, London, UK.

BSI (2012b) NA to BS EN 1995-1-1:2004+A1:2008 - UK National Annex to Eurocode 5: design of timber structures - part 1-1: general - common rules and rules for buildings. BSI, London, UK.

BSI (2014) BS EN 1995-1-1:2004+A2:2014: Eurocode 5: Design of timber structures. General. Common rules and rules for buildings. BSI, London, UK.

Griffiths R (1987) The Racking Resistance of Timber Frame Walls Assessed by Experimental and Analytical Techniques. $\mathrm{PhD}$ thesis, University of Surrey, Guildford, UK.

Griffiths R, Enjily V, Blass H and Kallsner B (2005) A unified design method for the racking resistance of timber framed walls for inclusion in Eurocode 5. Proceedings of CIB - W18 Meeting 38, Karlsruhe, Germany. Universitat Karlsruhe, Germany

Kallsnër B and Girhammar UA (2004) Influence of framing joints on plastic capacity of partially anchored woodframed shear walls. Proceedings CIB - W18 Meeting 37, Edinburgh, United Kingdom. Universitat Karlsruhe, Germany.

Porteous J and Kermani A (2013) Structural Timber Design to Eurocode 5, 2nd edn. Wiley-Blackwell, Oxford, UK.

\section{HOW CAN YOU CONTRIBUTE?}

To discuss this paper, please email up to 500 words to the editor at journals@ice.org.uk. Your contribution will be forwarded to the author(s) for a reply and, if considered appropriate by the editorial board, it will be published as discussion in a future issue of the journal.

Proceedings journals rely entirely on contributions from the civil engineering profession (and allied disciplines). Information about how to submit your paper online is available at www.icevirtuallibrary.com/page/authors, where you will also find detailed author guidelines. 